О. Г. Грохольская. - Иркутск : Оттиск, 2007. - 340 с. 3. Дружилов С. А. Становление профессионализма человека как реализация индивидуального ресурса профессионального развития / С. А. Дружилов. - Новокузнецк : Изд-во ИПК, 2002. - 242 с. 4. Дружилов С. А. Профессиональная компетентность и профессионализм педагога: психологический подход / C. А. Дружилов // Сибирь. Философия. Образование : [науч.-публицист. альманах].Новокузнецк. - 2005. - Вып 8. - С. 26-44. 5. Игнатьева Е. Ю. Педагогическое управление учебной деятельностью студентов в современном вузе: [монографія] / Е. Ю. Игнатьева.Санкт-Петербург : ЛЕМА. 2012. - 300 с. . Кулюткин Ю. Н. Психология обучения взрослых / Ю. Н. Кулюткин. - Москва : Просвещение, 1995. - 196 с. 7. Сенашенко В. С. О компетенциях, квалификации и компетентности / В. С. Сенашенко // Высшее образование в России. - 2010. - № 6. - С. 18-23. 8. Чепа М.-Л. А. Шлях від народження до смерті: осмислення сутнісних рівнів людського розвитку / М.-Л. А. Чепа // Проблеми загальної та педагогічної психології : [зб. наук. праць]. - Київ, 2001. - Т. ІІІ. - Ч. 2. - С. 123-129.

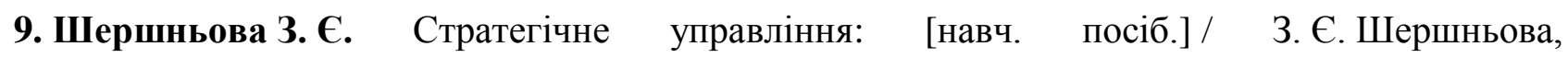
С. В. Обнорська. - Київ : КНЕУ, 1999. - 384 с.

\title{
ПЕДАГОГІЧНА МАЙСТЕРНІСТЬ ВИКЛАДАЧА ВИЩОЇ ШКОЛИ ТА ШЛЯХИ ЇЇ ПІДВИЩЕННЯ
}

Харченко I. І., Харченко С. М. Педагогічна майстерність викладача вищої школи та шляхи їі підвищення.

У статті розглянуто явище педагогічної майстерності викладача вищої школи, його особливості і структуру. Здійснено аналіз впливу педагогічної майстерності викладача на якість навчання у вищій школі. Узагальнено досвід вищих навчальних закладів щодо впровадження форм організації методичної роботи.

Ключові слова: педагогічна майстерність, професіоналізм, викладач вищого навчального закладу, педагогічні здібності, форми методичної роботи.

Харченко И. И., Харченко С. Н. Педагогическое мастерство преподавателя высшей школы и пути его повышения.

В статье рассмотрено явление педагогического мастерства преподавателя высшей школы, его особенности и структуру. Проведен анализ влияния педагогического мастерства преподавателя на качество учебы в высшей школе. Обобщен опыт вузов по вопросу внедрения форм организации методической работы.

Ключевые слова: педагогическое мастерство, профессионализм, педагогические способности, преподаватель высшего учебного заведения, формы методической работы.

Kharchenko I. I., Kharchenko S. N. Pedagogical excellence of higher school teachers and the ways of its increase.

The article analyzes the phenomenon of pedagogical excellence of higher school teachers as well as its features and structure. The influence of pedagogical excellence on the quality of studies at high school is analyzed. The experience of methodological work forms implementation among the higher educational establishments is generalized. 
Key words: pedagogical excellence, professionalism, pedagogical capabilities, instructors, methodological work forms.

Нині в Україні відбувається становлення нової системи освіти, орієнтованої на входження до світового освітнього простору. Цей процес супроводжується суттєвими змінами в педагогічній теорії і практиці навчально-виховного процесу. Перед вищою школою поставлено нові цілі і завдання, основним напрямом діяльності якої має стати задоволення потреб особистості у знаннях, які б можна було використовувати залежно від нових умов перетворення суспільства. А це насамперед вимагає належного кадрового супроводу, упровадження науково-обгрунтованої підготовки викладацьких кадрів для вищої школи.

В епоху новітніх інформаційних технологій, в період розвитку дистанційного навчання, пріоритетним джерелом систематизованої трансляції знань, їх незамінним ретранслятором є викладач, який забезпечує високу якість освіти. Це зумовлює потребу педагога в постійному самовдосконаленні, саморозвиткові, підвищенні своєї професійної майстерності. У контексті цієї проблеми особливий інтерес становить формування педагогічної майстерності. На сучасному етапі розвитку освіти вищому навчальному закладу потрібен викладач лабільний, спроможний до саморозвитку й самовизначення в ситуації, яка постійно змінюється, відкритий до соціального замовлення освіти, готовий до самовдосконалення, якісної, майстерної реалізації знань, умінь та навичок у професійній діяльності.

Однією 3 передумов розв'язання важливого і складного завдання 3 підготовки конкурентноздатних фахівців є розвиток педагогічної майстерності викладача вищої школи, зокрема, шляхом покращання психолого-педагогічної підготовки майбутніх викладачів та формування їх готовності до професійного самовдосконалення, саморозвитку, а через нього - продуктивної педагогічної діяльності. Масштабність досліджуваної проблеми вимагає розгляду розвитку педагогічної майстерності викладача вищого навчального закладу як багатофакторного, складного процесу.

Теоретичні засади формування педагогічної майстерності викладача вищої школи розроблені в працях Я. Коменського, К. Ушинського, А. Макаренка, О. Захаренка, І. Зязюна. Проблемою визначення сутності і змісту педагогічної майстерності опікувалися вітчизняні і зарубіжні дослідники А. Кузьмінський, І. Зязюн, О. Дубасенюк, Н. Кузьміна, А. Щербаков, Н. Кухарєв. Структуру педагогічної майстерності досліджували В. Кан-Калик, І. Кривонос.

Під час дослідження ми звернули увагу на вивчення наукових надбань, пов'язаних із підготовкою науково-педагогічних працівників, підвищенням їхньої кваліфікації та педагогічної майстерності в системі вищої професійної освіти, висвітлених у працях таких науковців: О. Коваленко, В. Гриньової, Н. Корогод, К. Корсак, В. Косарєва, М. Романенка, В. Семиченко.

Mema cmammi - визначити сутність поняття «педагогічна майстерність», виокремити головні складники майстерності педагога, шляхи підвищення педагогічної майстерності викладача вищого навчального закладу, проаналізувати, які форми методичної роботи та методи навчання використовуються для розвитку й удосконалення майстерності викладання у вищому навчальному закладі.

Результати дослідження засвідчили, що, незважаючи на значну кількість публікацій, присвячених проблемі педагогічної майстерності, однозначне розуміння сутності цього поняття фактично відсутнє і досить часто ототожнюється з професійною компетентністю. 
Показниками успішної професійної діяльності викладача $€$ комплекс таких взаємопов'язаних характеристик, як: педагогічна майстерність, професійна компетентність, професіоналізм, педагогічні здібності, між якими наявний зв'язок.

Під професійною компетентністю викладача розуміємо інтегроване особистісне утворення, що грунтується на теоретичних знаннях, практичних уміннях і особистісних якостях, що мають професійне значення, та досвіді, які забезпечують готовність до виконання педагогічної діяльності на високому рівні ii самоорганізації. Що стосується педагогічної майстерністі, то в українському педагогічному словнику це поняття визначається як характеристика високого рівня педагогічної діяльності, який грунтується на високому фаховому рівні педагога, його загальній культурі та педагогічному досвіді.

Науковець І. Зязюн розглядає сутність педагогічної майстерності з різних сторін: як найвищий рівень педагогічної діяльності (якщо ми характеризуємо якість результату), як вияв творчої активності особистості педагога (за умови, що ми характеризуємо психологічний механізм успішної діяльності) тощо. Власне «педагогічну майстерність» автор характеризує як комплекс властивостей особистості, що забезпечує самоорганізацію високого рівня професійної діяльності на рефлексивній основі [2, с. 30]. За визначенням I. Зязюна, педагогічна майстерність - це комплекс якостей особистості, що забезпечує високий рівень самоорганізації професійної діяльності педагога. Її складниками $\epsilon$ : 1) гуманістична спрямованість; 2) професійні знання; 3) педагогічні здібності; 4) педагогічна техніка.

Педагогічна майстерність у дослідженні розглядається як високе мистецтво здійснення вмотивованої навчально-виховної діяльності на основі засвоєної системи знань, умінь i навичок, особистісних якостей i педагогічного досвіду та виявляється в комплексному розв'язанні завдань освіти, виховання і розвитку на рефлексивному підгрунті. Педагогічна майстерність розглядається як складне, динамічне, інтегроване особистісне утворення, що включає стійке прагнення людини до діяльності в педагогічній галузі, наявність спеціальних знань, умінь і навичок, комплекс індивідуальних психічних i характерологічних особливостей, що забезпечують високу ефективність іiі подальшого професійного функціонування. Педагогічна майстерність включає: особистісний компонент, як єдність мотиваційно-ціннісної складової (професійно-педагогічної спрямованості) й індивідуально-психологічних особливостей (загальних $\mathrm{i}$ професійно-педагогічних здібностей); інформаційно-теоретичний компонент: спеціальні, методологічні, психологопедагогічні знання; діяльнісний компонент, який поєднує педагогічну технологію та техніку.

3'ясуємо, які вміння викладача і яким способом виявляються в підготовці й проведенні навчального заняття. Як відомо, організаційними етапами заняття є підготовчий етап, етап реалізації і аналітичний етап після завершення заняття. Підготовчий етап передбачає розроблення ідеї навчального заняття, створення його проекту, прогноз майбутнього заняття, створення моделі, підготовку методичного забезпечення. На цьому етапі практичної діяльності викладача реалізуються його гностичні, проективні, конструктивні й організаційні, аналітичні уміння. Характер реалізації підготовчого етапу залежить від викладача. Позитивні наслідки підготовчого етапу забезпечують, як правило, викладачі із творчою спрямованістю, відповідальні, організовані, сумлінні, добросовісні, із здатністю до аналізу. Набутий досвід, безперечно, позитивно впливає на якість підготовки викладача до заняття, оскільки надає змогу передбачити, що не зрозуміло студентам, але й водночас досвід є чинником, що може сприяти розвитку консерватизму викладача, його небажання використати нові підходи під час проектування навчального заняття. 
Можна виокремити низку компонентів у структурі педагогічної майстерності педагога:

1. Дидактичні здібності - здатність доступно і зрозуміло передавати студентам навчальний матеріал, викликати інтерес до предмета, збуджувати у студентів активну самостійну думку.

2. Академічні здібності - здібності до відповідної галузі науки. Здібний педагог повинен володіти предметом не тільки в обсязі навчального курсу, а значно ширше і глибше, постійно стежити за новинками у своїй галузі, абсолютно вільно володіти матеріалом, виявляти до нього великий інтерес, виконувати наукову роботу, впроваджувати сучасні новітні методики викладання, активно застосовувати в навчальному процесі Інтернет, комп’ютерні технології та програми.

3. Перцептивні здібності. Велику роль відіграють перцептивні (тобто здатність визначати емоційний стан людини за іï мімікою, позою, жестами) та сугестивні (здатність чинити вплив на людину, змінюючи характер іiі діяльності) уміння викладача. У процесі навчання ці групи умінь набувають різного значення. За мімікою, позою та жестами студентів викладач визначає їхній стан готовності до заняття, прагнення брати активну участь у навчальній діяльності або бажання уникнути іiі, психофізичний стан, рівень розуміння навчального матеріалу або рівень утруднень при осмисленні тощо. Результати спостережень дозволяють викладачеві коригувати навчальний процес і міжособистісні стосунки, що складаються в ньому.

4. Мовні здібності - уміння ясно і чітко висловлювати свої думки і почуття засобами мови, а також міміки і пантоміміки. Це одна 3 найважливіших здібностей у професії педагога, тому що в навчальному процесі передача інформації має переважно словесний характер.

5. Організаторські здібності. Організаторський компонент педагогічної діяльності є чи не найважливішим, тому що від сформованості цієї групи умінь залежить рівень і якість практичної роботи викладача. До організаторських здібностей та умінь можна віднести: уміння організовувати свою власну діяльність відповідно до поставленої мети; вміння раціонально розподіляти час діяльності; здатність до самоконтролю, вміння дотримуватись плану діяльності; здатність контролювати темп навчання; уміння організовувати навчальну діяльність студентів і контролювати їх діяльність, переключати студентів на інший вид діяльності; уміння здійснювати контроль за діяльністю студентів, оцінювати якість виконаної ними роботи; вміння формувати вимоги до студентів і домагатися їхнього виконання; вміння створити ситуацію співучасті студентів під час навчального процесу.

6. Здатність до розподілу уваги одночасно між декількома видами діяльності має особливе значення. Здібний, досвідчений педагог повинен уважно стежити за змістом i формою викладу матеріалу, за розгортанням своєї думки (або думки студента), одночасно тримати в полі зору всіх студентів, вчасно реагувати на ознаки стомлення, неуважності, нерозуміння, помічати усі випадки порушення дисципліни i, нарешті, стежити за власною поведінкою (позою, мімікою і пантомімікою, ходою). Недосвідчений викладач, нерідко захоплюючись викладом матеріалу, не помічає в цей час студентів, а якщо намагається уважно спостерігати за ними, то втрачає при цьому логіку викладу.

7. Комунікативні здібності - здібності до спілкування зі студентами, уміння знайти до них правильний підхід, налагодити 3 ними доцільні з педагогічного погляду взаємини, педагогічний такт.

Показники професійної готовності випускника вищого навчального закладу, 
трансформуючись у кінцевому результаті в професійну компетентність, розглядаються як основа розвитку педагогічної майстерності викладача вищої школи. Обгрунтована структура педагогічної майстерності сучасного викладача вищого навчального закладу охоплює: професійну компетентність (система необхідних знань, умінь i навичок, володіння сучасними технологіями і стратегіями розв'язання дидактичних проблем, презентабельність особистого досвіду, здатність до одержання і трансформації необхідної інформації тощо; готовність до творчої професійної діяльності (вмотивоване професійне самовизначення, здатність до рефлексії, досвід педагогічної роботи, професійна мобільність, наявність програми самовдосконалення тощо); педагогічні здібності (перцептивні, креативні, комунікативні, емоційно-регулятивні); особистісні якості, що мають професійне значення (цілеспрямованість, толерантність, чесність, оптимізм тощо); педагогічну техніку (мовлення, міміка, театралізація, організація педагогічної взаємодії, адекватне спілкування тощо).

Шляхи розвитку педагогічної майстерності передбачають: орієнтацію на упередження ймовірних кількісно-якісних соціально-економічних i культурологічних характеристик розвитку суспільства; урахування тенденцій навчально-виховних завдань; осмислення та адаптації взаємопов'язаних процесів глобалізації й одночасної регіоналізації освітніх систем; забезпечення формування особистості як суб’єкта свого самовизначення на засадах особистісно зорієнтованого, компетентнісного підходів. Як зазначає М. Фіцула, з метою підвищення професійної майстерності викладачів у ВНЗ використовують різноманітні форми методичної роботи: а) науково-практичні конференції викладачів; б) загальні конференції педагогічних працівників вищої школи, де обговорюється стан навчально-виховного процесу у ВНЗ, на факультетах, а також перспективи розвитку фахових спеціальностей; в) засідання вченої ради закладу, на яких детально аналізують рівень професійної підготовки студентів, стан навчально-виховної роботи на факультетах, обговорюють i затверджують перспективний план роботи вищого навчального закладу за окремими проблемами (наприклад, науково-дослідна робота студентів, методична робота з викладачами та ін.), а також розглядають досвід роботи кафедр, факультетів щодо впровадження нових технологій навчання студентів; г) методичні семінари; г) засідання кафедр, на яких обговорюють результати роботи викладачів щодо вдосконалення навчально-виховної роботи зі студентами; д) інструктивно-методичні наради, які проводяться деканами факультетів; е) індивідуальна самоосвітня робота викладача вищої школи; є) індивідуальні та групові консультації із завідувачами кафедр та викладачами з реалізації управлінських функцій або для надання конкретної методичної допомоги кафедрам з питань планування роботи, визначення змісту, форм наукової, організаційно-методичної роботи. Ефективними формами методичної роботи, як визначає М. Фіцула, є написання і підготовка до видання конспектів лекцій, методичних матеріалів до семінарських занять, лабораторних робіт, курсового та дипломного проектування, практики і самостійної роботи студентів; розроблення робочих навчальних планів, робочих навчальних програм; розроблення i постановка нових лабораторних робіт; підготовка комп'ютерного програмного забезпечення навчальних дисциплін: складання екзаменаційних білетів, завдань для проведення модульного, тестового i підсумкового контролю; розроблення і впровадження наочних навчальних посібників (схем, діаграм, стендів, слайдів тощо), нових форм, методів і технологій навчання; вивчення і впровадження передового досвіду організації навчального процесу; підготовка персональних художніх виставок та ін. [5, с. 333].

Дотримуючись точки зору М. Фіцули, на нашу думку, є дієвими такі форми науковометодичної роботи, як: засідання вченої ради академії; науково-практичні конференції; 
круглі столи; засідання вченої ради факультетів; методичні семінари; виробничі наради; засідання кафедр; інструктивно-методичні наради, які проводяться деканами факультетів; робочі групи; індивідуальна самоосвітня робота викладача; «Школа педагогічної майстерності»; «Майстер-клас»; виставка кращого навчально-методичного забезпечення дисциплін; конкурс на краще навчальне видання; огляд-конкурс за номінаціями «Краща кафедра», «Кращий викладач»; стажування; наставництво; взаємовідвідування занять.

Як бачимо, рівень педагогічної майстерності викладача вищої школи є важливим чинником навчально-виховного процесу, він позначається на результатах навчання студентів, на формуванні їх як особистостей. У свою чергу, розвиток педагогічної майстерності викладача корелює 3 його ставленням до себе, вимогами до своєї діяльності, особистісними якостями. Можна вивчити свій фаховий предмет, мати систему психологопедагогічних знань, але це не забезпечить відповідної майстерності.

Комплексне використання активних форм і методів сприяє закріпленню теоретичних знань, озброєнню викладачів необхідним методичним арсеналом розв'язання сучасних освітніх проблем вищої школи, формують здатність до рефлексії, уміння використовувати одержану інформацію в нових умовах, а також удосконалювати свої інтелектуальні, світоглядні і комунікативні якості.

Сучасна вища школа має багатий арсенал форм підвищення педагогічної майстерності науково-педагогічних працівників, для дипломованого фахівця різноманітні форми організації методичної роботи, організовані на робочому місці, є способом підвищення професійної майстерності. У подальшій своїй роботі ми плануємо вивчити досвід аграрних ВНЗ щодо використання педагогічних технологій та інтерактивних методів навчання.

\section{Література}

1. Заболоцька О. С. Компетентнісний підхід як освітня інновація: порівняльний аналіз / О. С. Заболоцька // Вісник Житомирського державного університету. - 2008. Випуск 40. - Педагогічні науки. - С. 63-68. 2. Зязюн I. А. Педагогічна майстерність / І. А. Зязюн. - Київ : Вища школа, 1997. - С. 30-49. 3. Ортинський В. Л. Педагогіка вищої школи: навч. посіб. [для студ. вищ. навч. закл.] / В. Л. Ортинський. - Київ : Центр учбової літератури, 2009. - 472 с. 4. Обривкіна О. М. Сучасні форми методичної роботи 3 підвищення педагогічної майстерності викладачів в університеті [Електронний ресурс]/ О. М. Обривкіна. Режим доступу: //www.nbuv. gov.ua/portal/soc_gum/nvnau_ppf/2010/10oom.pdf. 5. Фіцула М. М. Педагогіка вищої школи: [навч. посіб.] / М. М. Фіцула. - Київ : Академвидав, 2006. - 352 с.

УДК 378.147

Наталія Чувасова

\section{ФОРМУВАННЯ ТВОРЧОГО ПОТЕНЦІАЛУ МАЙБУТНІХ УЧИТЕЛІВ ХІМІЇ ТА БІОЛОГІЇ У ПРОЦЕСІ ФАХОВОЇ ПІДГОТОВКИ}

Чувасова Н. О. Формування творчого потенціалу майбутніх учителів хімії та біології у процесі фахової підготовки.

У статті на основі зіставлення, порівняння, узагальнення наукової інформації феноменів «творчість», «творча особистість», «потенціал», «творчий потенціал» розглядаються різні підходи до визначених понять. Виокремлено якості, чинники творчого потенціалу та риси його розвитку.

Ключові слова: творчість, творчий процес, творча особистість, творчий потенціал.

Педагогіка вищої та середної школи. - 2015. - Вип. 45 